Life Sciences Contributions

Royal Ontario Mușeum

127

The Planarians (Turbellaria) of Temporary Waters in Eastern North America

Ian R. Ball

N. Gourbault

Roman Kenk

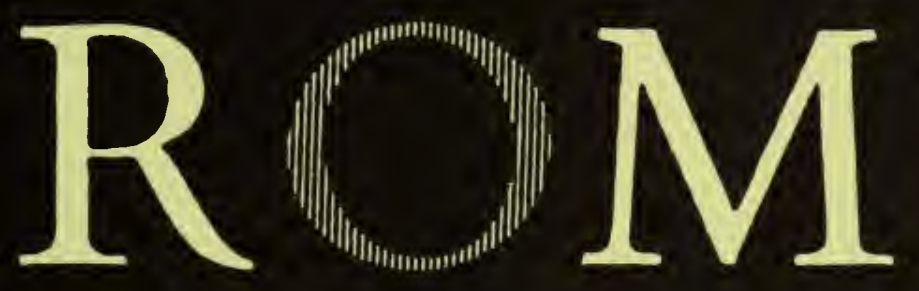




\section{ROYAL ONTARIO MUSEUM LIFE SCIENCES PUBLICATIONS INSTRUCTIONS TO AUTHORS}

Authors are to prepare their manuscripts carefully according to the following instructions. Failure to do so will result in the manuscript's being retumed to the author for revision. All manuscripts are considered on the understanding that if accepted they will not be offered for publication elsewhere.

1. GENERAL Papers for publication are accepted from ROM staff members, Research Associates, or from researchers reporting on work done with ROM collections. In exceptional cases, monographic works on the flora and/or fauna of Ontario will be considered for publication by authors not affiliated with the ROM. Authors are expected to write clearly and concisely, and to omit all material not essential for an understanding of the main theme of the paper.

2. FORMAT Manuscripts are to be typed double-spaced (including captions, synonomies, literature cited, and tables) on 11 " $\times 81 / 2$ " paper with a $1 \frac{1}{2}$ " margin on all sides. Three xerox copies are to be submitted to the Chairman of the Editorial Board, and the original retained by the author(s). A separate sheet is to be submitted giving author(s) names, affiliation, title of publication, series in which it is to appear, number of typed pages, number of tables, and number of figures. Manuscripts should normally be organized in the following order: Table of Contents, Abstract, Introduction, Materials and Methods, Results, Discussion, Conclusions, Summary (if paper is long), Acknowledgements, Literature Cited, and Appendices. Authors are encouraged to include foreign language translations of the Summary where appropriate. Headings of sections are to be left-justified to the text margin. The first line of the first paragraph in each new section should not be indented. Text-figures are referred to as "Fig. 1". Literature cited in the text is in the form "Jones (1972)" or "(Jones, 1972)" or "(Smith, 1960:71-79, fig. 17)".

3. STANDARD SOURCES The primary source for decisions on format and style is A Guide for Contributors and Editors of ROM Life Sciences Publications, available from the Chairman of the Editorial Board. Otherwise, consult CBE (AIBS) Style Manual (3rd Edition). Other standard sources are as follows: for English spelling (Concise Oxford Dictionary), for Canadian place names and coordinates (Gazetteer of Canada), and for spelling of geographic names (Times [London] Atlas).

4. ABSTRACT All papers are preceded by a short and factual abstract, about 3 per cent as long as the text, but not longer than 400 words. The abstract is to be followed by four to six keywords enclosed in brackets.

5. TAXONOMY The name of a taxon is given in full in headings, where it appears for the first time, or when the name begins a paragraph. Use authority and date if appropriate, with first mention of each taxon and not thereafter. Taxonomic papers follow the layout in Life Sciences Contribution 99, particularly the synonomies.

6. LITERATURE CITED References in the text cite author and date and are enclosed in parentheses (Smith, 1978). Complete references are listed in alphabetical order by author at the end of the paper. When there are two or more citations for an author, the works are listed chronologically. Names of journals are not abbreviated. Consult Life Sciences Contributions beginning with 117 for correct bibliographic form.

7. TABLES All tables are numbered consecutively in arabic numerals in numerical order of their first mention in the text. Mark the appropriate text location of each table with a marginal notation. Each table is typed on a separate sheet. Avoid footnotes etc., to tables by building them into the title.

8. FIGURES All figures are numbered consecutively in arabic numerals. Component photographs or drawings are labelled sequentially in upper case letters. Mark the appropriate text location of each figure with a marginal notation. The intended reduction for figures is ideally one and a half to two times. All labelling on figures is in blue pencil and not inked or letraset. Halftones must be photographic prints of high contrast on glossy paper. Authors are to submit $10^{\prime \prime} \times 8^{\prime \prime}$ copies with the MS and retain originals until they are requested. Figure captions are to appear grouped together on a separate page at the end of the MS. 
LIFE SCIENCES CONTRIBUTIONS

ROYAL ONTARIO MUSEUM

NUMBER 127

IAN R. BALL

N. GOURBAULT ROMAN KENK
The Planarians (Turbellaria) of Temporary Waters in Eastern North America 


\section{ROYAL ONTARIO MUSEUM PUBLICATIONS IN LIFE SCIENCES}

The Royal Ontario Museum publishes three series in the Life Sciences:

LIFE SCIENCES CONTRIBUTIONS, a numbered series of original scientific publications including monographic works.

LIFE SCIENCES OCCASIONAL PAPERS, a numbered series of original scientific publications, primarily short and usually of taxonomic significance.

LIFE SCIENCES MISCELLANEOUS PUBLICATIONS, an unnumbered series of publications of varied subject matter and format.

All manuscripts considered for publication are subject to the scrutiny and editorial policies of the Life Sciences Editorial Board, and to review by persons outside the Museum staff who are authorities in the particular field involved.

\section{LIFE SCIENCES EDITORIAL BOARD}

Senior Editor: A. J. BAKER

Editor: C. McGOWAN

Editor: P. H. von BITTER

IAN R. BALL is Professor in Systematic and Geographical Zoology, University of Amsterdam, The Netherlands; Adjunct Professor, Department of Biology, University of Waterloo, Waterloo, Ontario; Research Associate, Department of Vertebrate Palaeontology, Royal Ontario Museum; and Honorary Research Associate of the School of Graduate Studies, University of New Brunswick, Fredericton, New Brunswick.

NICOLE GOURBAULT is a CNRS Research Scientist in the Laboratoire des Vers, Muséum National d'Histoire Naturelle, Paris, France.

ROMAN KENK is a Research Associate in the Department of Invertebrate Zoology, National Museum of Natural History, Smithsonian Institution, Washington, DC 20560, USA.



Publication date: 10 April 1981

ISBN 0-88854-274-7

ISSN 0384-8159

(C) 1981, The Royal Ontario Museum

100 Queen's Park, Toronto, Canada M5S 2C6

PRINTED AND BOUND IN CANADA AT THE ALGER PRESS 


\section{Contents}

Abstract 1

Introduction 1

Abbreviations Used in the Figures

2

Systematic Section 3

The genus Hymanella 3

Hymanella retenuova 3

The genus Phagocata 9

Phagocata velata 9

Recognition of the Species

13

The Status of Phagocata vernalis and its Relationship to Hymanella retenuova 15

Planarians in Temporary Waters 18

Acknowledgements $\quad 20$

Summary 21

Sommaire 22

Zusammenfassung 23

Literature Cited 24 
Digitized by the Internet Archive in 2011 with funding from University of Toronto 


\title{
The Planarians (Turbellaria) of Temporary Waters in Eastern North America
}

\begin{abstract}
There are only two species of planarians that occur regularly in temporary ponds in eastern North America: Hymanella retenuova and Phagocata velata. The so-called typical vernal pond form, $P$. vernalis, is in reality a mixed description of the two species. Phagocata velata withstands desiccation by a modification of the asexual cycle involving multiple fragmentation and encystment. $H$. retenuova is protandrous and produces a thick-shelled resistant cocoon; it does not reproduce asexually. Revisions of these species, including new karyological data, are given together with descriptions of methods for their identification. The paper concludes with a brief general review of our knowledge concerning planarians in temporary waters.
\end{abstract}

\section{Introduction}

Few freshwater planarians have been able to establish themselves successfully as permanent inhabitants of temporary waters. In general the life cycle is simple, without resistant stages, and the adults are fragile and susceptible to desiccation and high temperatures. Those species that have been able to adapt their life cycles to life in temporary waters belong, so far as is known, exclusively to the genera Phagocata and Hymanella. The adaptation of the species to vernal ponds has been achieved by modifications of the sexual cycle in Hymanella and of the asexual cycle in Phagocata.

Hymanella retenuova, the sole member of the genus, is the only aquatic planarian known that produces a thick-shelled cocoon capable of withstanding drought. This species is known from a few vernal ponds of eastern North America ranging from southern Ontario to Louisiana. Also in North America there are two undoubtedly valid species of Phagocata that exhibit modification of their asexual cycle which permits existence in temporary waters. Phagocata velata is to be found in vernal ponds throughout eastern North America and $P$. fawcetti is a recently described species from intermittent streams in California (Ball and Gourbault, 1975). Both these species undergo multiple fission or fragmentation at unfavourable times and each fragment secretes a layer of slime which hardens into a resistant cyst.

It has long been known that Phagocata velata may be found in two very different types of habitat; apart from vernal ponds, it also inhabits springs and spring-fed 
streams. As a result of his investigations of temporary ponds in Michigan, Kenk $(1944,1949)$ concluded that $P$. velata really comprised two species, externally identical, that had been confused. $P$. velata (sensu stricto) occupied the spring habitats and a new species, $P$. vernalis Kenk, which was anatomically distinct, occupied the vernal ponds. Sexual maturity, essential for precise identification, was a rare event in both species thus making their identification or separation a difficult task.

The problems of recognition of the temporary pond planarians were further compounded when it was recognized that the original description of Hymanella retenuova by Castle (1941) contained errors (Hyman, 1955). In the late reproductive state this species is easily identified because it retains the conspicuous oval cocoon in the atrium for several days. But Castle described the external appearance of this species wrongly and Hyman (1955) was the first to note the Phagocata-like appearance of living specimens. This observation was confirmed by Kenk (1970) who believed it impossible to distinguish the species in life, by external characters, from Phagocata velata, $P$. vernalis, $P$. crenophila, or Planaria dactyligera, the last two species not being inhabitants of temporary ponds. Thus, at present, the temporary pond planarians of eastern North America are deemed to comprise three species which cannot be distinguished in life by external characters, and which are rarely found in the sexual state, at least in the case of the Phagocata species.

The present investigation was initiated in 1968 in an attempt to elucidate the taxonomic status of the three species and to seek means of identifying them so as to facilitate ecological work on the interesting fauna of vernal habitats. The suspicion was aroused that Hymanella retenuova and Phagocata vernalis were conspecific, the latter originally having been described on the basis of observations on a mixed population of $P$. velata and $H$. retenuova (Ball, 1974:360; 1975:399). Conspecificity can now be demonstrated on morphological, cytological, and biological grounds. The apparent differences between the two species as originally described are a product of the unusual life cycle of $H$. retenuova and of the fact that the original description of this latter species by Castle (1941) is erroneous in some important respects.

Thus, only two species of freshwater planarians, Hymanella retenuova and Phagocata velata, are regular inhabitants of vernal ponds in eastern North America. In this paper we present revisions of these two species, including new karyological data, and then review the evidence leading to the conclusion that $P$. vernalis and $H$. retenuova are conspecific. The paper concludes with a brief synopsis of our knowledge concerning planarians in temporary waters which serves mainly to emphasize how little we know of this interesting topic.

\section{Abbreviations Used in the Figures}

\begin{tabular}{|c|c|c|}
\hline c bursa copulatrix & $\mathrm{pb}$ & penis bulb \\
\hline bursal duct & po & pharyngeal pore \\
\hline diverticulum & $\mathrm{pp}$ & penis papilla \\
\hline ejaculatory duct & $\mathrm{sg}$ & shell glands \\
\hline gonopore & sv & seminal vesicle \\
\hline $\begin{array}{l}\text { male atrium } \\
\text { common oviduct }\end{array}$ & $\mathrm{vd}$ & vas deferens \\
\hline
\end{tabular}




\section{Systematic Section}

\section{Genus Hymanella Castle, 1941}

Planariidae with two eyes and truncated or rounded head; testes fused, prepharyngeal male atrium without radial muscle plates; adenodactyls absent; shell glands open into upper part of common oviduct only; cocoon thick walled, oval, and without a stalk; protandrous. Type species Hymanella retenuova Castle.

\section{Hymanella retenuova Castle}

(Figs. 1-5)

Hymanella retenuova Castle, $1941: 85$

Hymanella retenuova-Hyman, 1955:30; Ball, 1969:61; 1974:360; Kenk, $1970: 15 ; 1972: 31 ; 1974: 34$

Planaria simplississima-Chidester, 1908:226

Phagocata vernalis Kenk, 1944:22, new synonymy

Fonticola vernalis (Kenk)—Ball, 1969:60

Phagocata vernalis -Darlington and Chandler, 1972:161; Kenk, 1972:34

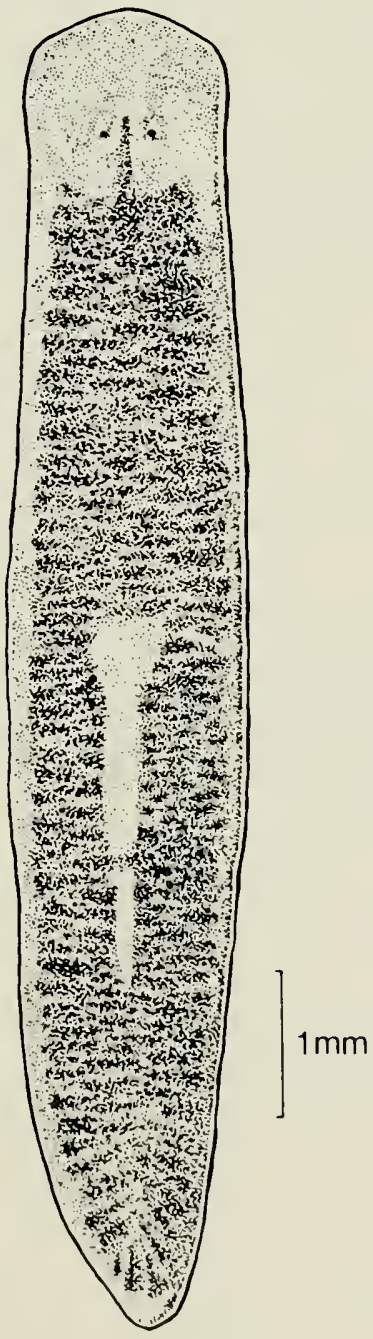

Fig. I Hymanella retenuova. Drawing of a living animal from Erbsville, Waterloo County, Ontario. 


\section{Description}

Maximum size $14 \mathrm{~mm} \times 2.3 \mathrm{~mm}$, although specimens half this size may be sexually mature. Head rounded or truncate, occasionally very slightly spatulate; never seen to be triangular as described by Castle (1941). Eyes two, distant from the anterior margin. Anterior ramus of the intestine rarely extends between the eyes. Auricular streaks not evident. When in motion the body margins are smooth and nearly parallel, tapering to a blunt point at the posterior end. When at rest the margins are thrown into folds and frills. The colour is a transparent grey or brown, the pigment is uniformly distributed, but not so densely as to obscure the outline of the intestine. The area immediately surrounding each eye is not pigmented. The ventral surface is a little paler than the dorsal. The cocoon is unstalked and ellipsoid, about $1.75 \mathrm{~mm} \times$ $1.00 \mathrm{~mm}$, and of a deep red-wine colour. It is retained in the atrium for several days prior to being deposited.

The paired ovaries are small (ca $150 \mu \mathrm{m} \times 100 \mu \mathrm{m}$ ), compact, and situated ventrally in the region of the second and third intestinal diverticula. They lie dorsal and medial to the ventral nerve trunks. When present the parovaria lie dorsal and somewhat lateral to the ovaries. The oviducts run ventrally, just above the nerve trunks, to the level of the posterior part of the male atrium. At this point they turn dorsad and mediad and unite beneath the bursal duct to form a common oviduct which opens into the roof of the atrium immediately anterior to the opening of the bursal duct. The shell glands, which may be extensive, open only into the upper part of the common oviduct. The vitellaria extend from the level of the ovaries to the posterior end of the animal, and fill the parenchymal spaces between the intestinal diverticula. They reach to both the dorsal and ventral body walls, but do not occur between the two principal posterior intestinal branches in the region of the copulatory organs.

The testes show an unusual arrangement. Normal follicular testes are absent. In their place there is, on each side of the body, a single fused or compound testis that extends from just behind the ovary to half-way along the pharynx. Each testis is situated medially to the oviduct and to the ventral nerve trunk. The testes consist of a thin tube with regular dilatations which contain the developing sperm. The exact number of the dilatations is difficult to discern, but there are probably eight to twelve on each side. It appears that each testis serves as both male gonad and sperm duct.

The bursa copulatrix is a sacciform organ lying between the penis and the pharyngeal pouch. It is quite narrow laterally, and in some specimens may extend along the sides of the pharyngeal pocket. The narrow bursal duct runs dorsally to the copulatory complex, curving slightly to the right, and then bends ventrad to open into the atrium almost at the gonopore (Figs. 2, 3). Its musculature of intermingled circular and longitudinal fibres is very weak.

The gonopore leads into a male atrium of extraordinary shape and dimensions (Fig. 2). Dorsoventrally it is large, about half the thickness of the animal, but in the horizontal plane it is very narrow, and in female mature animals that have not held cocoons it may occupy no more than one-tenth of the body width. In younger specimens the dimensions are more normal.

At the anterior end of the male atrium is situated the penis. There is a muscular hemispherical bulb embedded in the parenchyma and from this projects the penis papilla. In male mature animals the papilla is a large conical organ that completely fills the male atrium (Fig. 3). After copulation the penis degenerates, loses much of its muscularity, and the papilla becomes weak and very small (Fig. 2). Most 


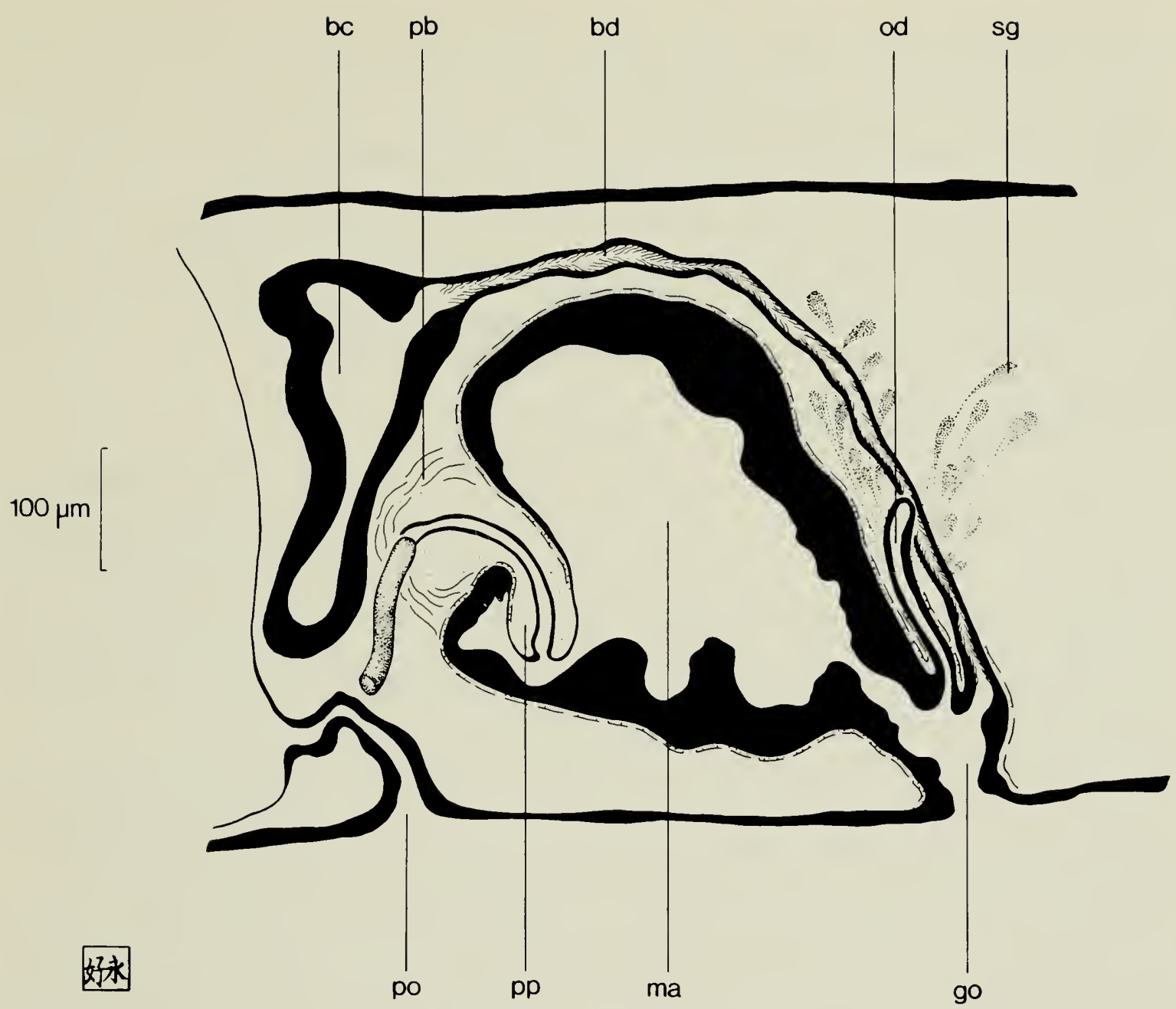

Fig. 2 Hymanella retenuov'a. Sagittal section, viewed from the left side, through the copulatory apparatus of a female-mature specimen from Erbsville, Waterloo County, Ontario (ROM C81).



Fig. 3 Hymanella retenuova. Sagittal section, viewed from the left side, through the copulatory apparatus of a male-mature specimen from Maryland (USNM 1602A). 
descriptions of $H$. retenuova refer to this latter condition (see below). With the regression of the penis a large space is left in the atrium, which now develops a tall papillose epithelium, for the reception of the oval thick-walled and resistant egg capsule. The vasa deferentia are thin tubes that first become conspicuous at the level of the pharynx. Just posterior to the pharynx they turn upward and travel directly, without convolutions, to the penis bulb, which they enter independently. Within the bulb they unite to form the symmetrically placed ejaculatory duct that opens at the tip of the papilla. Usually there is no intrabulbar seminal vesicle, but in fully male-mature specimens a small one may be apparent (Fig. 3).

\section{Distribution and Biology}

Hymanella retenuova is restricted almost entirely to vernal ponds. Established data indicate its occurrence in such habitats in southern Ontario (Ball, 1969), Michigan (Kenk, 1944, as Phagocata vernalis), Massachusetts (Castle, 1941), Delaware (Hyman, 1955), North Carolina (Hyman, 1955), Tennessee (Darlington and Chandler, 1972, as Phagocata vernalis), and Louisiana (Longest, 1966). The species has also been found in a spring-fed swamp in Massachusetts (Castle, 1941) and in a seepage spring in North Carolina (Kenk, 1970).

To these records the following unpublished data may be added. North Carolina: Warren Laboratories, near Warrenton, in seepage springs, together with Phagocata bulbosa and Planaria dactyligera musculosa, collected by R. Kenk, 12 June 1968 . Maryland: temporary pool near Sandy Point State Park, Anne Arundel County. A few specimens collected by Arnold Norden on various dates, 3 May 1973, 2 March 1975, 23 February 1976. Also recovered from samples of debris taken 24 January 1976 (when the pool was covered with ice) and in February 1976. On 26 February and 11 March 1976 Norden visited the pool at night and found great numbers of active Hymanella and Phagocata velata. Maryland: pond near Ernestville, Washington County, from a sample of debris collected by A. Norden, 26 March 1976. Many individuals showed a heavy infestation with parasites.

It is likely that this species reproduces entirely by sexual means for architomy has not been reported and nor has fragmentation of the type found in Phagocata velata. Hymanella retenuova withstands the desiccation of temporary habitats by producing a large thick-shelled cocoon. It seems, however, that desiccation is not a necessary condition for hatching because in specimens provided by Norden, and cultured at $14^{\circ} \mathrm{C}$ in Washington by Kenk, many cocoons were deposited, some of which hatched after several months.

Brief notes on the life cycle in Massachusetts have been provided by Castle (1941). In one of the Ontario ponds (Erbsville, Waterloo County) specimens were first apparent in mid-April, the population reached a peak in mid-May and then gradually waned until by mid-June, even though the pond was still wet, active specimens could not be found. Cocoon production seemed to be confined to the last one or two weeks of May, and according to Castle (1941) cocoons may be held in the body for 10 to 27 days. In Maryland the cycle occurs somewhat earlier. Norden (in litt.) kept a small vernal pool in Anne Arundel County under observation between 1974 and 1976. In the latter year he found Hymanella retenuova to be abundant in all developmental stages, including individuals carrying cocoons, during the months of February and March.

Casual observations of the Ontario pond between 1969 and 1971 suggest that the extremely rapid life cycle of this species lags slightly behind the cycle of 
fairy-shrimps (Phyllopoda) that inhabit the same pond. It is suspected that $H$. retenuova feeds primarily upon these organisms, a suspicion reinforced by Kenk's laboratory observations that the species is difficult to culture unless fed on crustaceans. It does not thrive on dried blood or beef liver in contrast to most freshwater planarians. A thorough ecological study of this planarian evidently would be most valuable and interesting.

Canadian specimens of Hymanella retenuova have been found to be entirely free of parasites or epizoites. It is noteworthy that its cohabitant, Phagocata velata, is usually heavily epifaunated with the peritrichous ciliate Urceolaria mitra (von Siebold), and frequently heavily parasitized with sporozoans. However, one population from Maryland was found in which many of the individuals also were infected with sporozoans.

\section{Karyology (Figs. 4-5)}

Hymanella retenuova shows a high level of regeneration and therefore mitosis has been investigated as usual in neoblasts of regenerative blastemas (Ball and Gourbault, 1975). Karyological studies have been carried out on living animals collected in April and May of 1974 from Ponds 1 and 2 in Michigan (Kenk, 1949) and from one locality in Ontario (Erbsville, Waterloo County). The results are similar in the three populations studied.

The diploid complement consists of 38 elements (Figs. 4, 5) varying in size from 2.5 to $10 \mu \mathrm{m}$. In all the metaphase plates analysed, the number of chromosomes appears very clearly and for five especially clear somatic plates the means of the relative lengths and the centromeric indices of these chromosomes have been calculated and are presented in Table 1. An idiogram analysis is given as Fig. 5. The first large pair of chromosomes are the most metacentric, others are at the boundary of submetacentrics, and nine are typical submetacentrics (c.i. < 37) according to the nomenclature of Levan et al. (1964).

Although most of the specimens examined were sexually mature, a proper study of meiosis was not possible because the auxocytes were not found in a sufficiently

Table 1 Relative length and centromeric index of the 19 chromosome pairs of Hymanella retenuova. Means and standard deviations from five metaphase plates.

\begin{tabular}{lllcrr}
\hline Chromosome & $\begin{array}{l}\text { Relative } \\
\text { Length }\end{array}$ & $\begin{array}{c}\text { Centromeric } \\
\text { Index }\end{array}$ & Chromosome & $\begin{array}{l}\text { Relative } \\
\text { Length }\end{array}$ & $\begin{array}{c}\text { Centromeric } \\
\text { Index }\end{array}$ \\
\hline 1 & $11.25 \pm 0.43$ & $48.03 \pm 0.43$ & 11 & $4.71 \pm 0.15$ & $39.05 \pm 6.03$ \\
2 & $7.60 \pm 0.35$ & $34.22 \pm 1.14$ & 12 & $4.66 \pm 0.15$ & $41.07 \pm 2.90$ \\
3 & $6.46 \pm 0.27$ & $31.54 \pm 3.60$ & 13 & $4.48 \pm 0.18$ & $37.70 \pm 3.10$ \\
4 & $5.95 \pm 0.17$ & $43.29 \pm 2.57$ & 14 & $4.37 \pm 0.12$ & $29.46 \pm 4.29$ \\
5 & $5.48 \pm 0.21$ & $33.57 \pm 3.20$ & 15 & $4.26 \pm 0.11$ & $40.31 \pm 1.56$ \\
6 & $5.45 \pm 0.18$ & $41.04 \pm 3.52$ & 16 & $4.04 \pm 0.09$ & $32.28 \pm 3.70$ \\
7 & $5.29 \pm 0.17$ & $36.01 \pm 7.42$ & 17 & $3.90 \pm 0.14$ & $36.33 \pm 4.86$ \\
8 & $5.22 \pm 0.17$ & $38.62 \pm 3.42$ & 18 & $3.66 \pm 0.12$ & $38.77 \pm 2.33$ \\
9 & $4.96 \pm 0.09$ & $41.76 \pm 3.68$ & 19 & $3.08 \pm 0.27$ & $40.00 \pm 2.08$ \\
10 & $4.86 \pm 0.08$ & $35.04 \pm 4.97$ & - & - & -
\end{tabular}






Fig. 4 Hymanella retenuova. Diagram of a metaphase plate from a specimen from Michigan.



Fig. 5 Hymanella retenuova. Idiogram analysis based on the data in Table 1. 
differentiated stage. Both the oocytes in the ovaries, and the spermatocytes in the testes, which are difficult to see, have been observed in pachytene or diffuse stages. However, in culture in Paris the specimens yielded more than 60 cocoons, three of which hatched, each producing two young.

The most striking feature of the karyotype of $H$. retenuova is its great overall similarity to that of Phagocata fawcetti (Ball and Gourbault, 1975), including the presence of a pair of large "marker" chromosomes, a fact indicating the close relationship of Hymanella to the American species of the genus Phagocata. These marker chromosomes are also apparent in European species of the genus (Dahm, 1964; Benazzi and Gourbault, 1974).

\section{Genus Phagocata Leidy, 1847}

Planariidae with two eyes, and usually with a truncated or rounded head; testes follicular, rarely showing fusion; male atrium without radial muscle plates; adenodactyls absent. Cocoons spherical or oval, and unstalked. Type species: Planaria gracilis Haldeman, 1840. (The problems of defining or diagnosing this genus have been discussed in detail by Ball and Gourbault, 1975.)

\section{Phagocata velata (Stringer)}

(Figs. 6-9)

Planaria velata Stringer, 1909:258

Fonticola velata-Kenk, 1930:293

Phagocata velata-Hyman, 1937:307

Phagocata vernalis Kenk, 1944:22, in part, new synonymy

Phagocata gracilis monopharyngea Hyman, 1945:475, new synonymy

Fonticola gracilis monopharyngea-Ball, 1969:19, new synonymy

Phagocata monopharyngea-Kenk, 1972:33, new synonymy

\section{Description}

Maximum size $20 \mathrm{~mm} \times 2 \mathrm{~mm}$, although in nature the species rarely exceeds $15 \mathrm{~mm}$ in length. The head is truncate, often with a slight convex projection of the mid-anterior margin, and rounds laterally to give the effect of a neck region. Eyes two, a little further removed from the anterior than from the lateral margins. Anterior ramus of the intestine usually extends between the eyes. Body margins smooth and tapering to a blunt point at the posterior end. The dorsal surface may be grey, brown, or black, often with a dark medial line behind the pharynx. The ventral surface is pale. The cocoon is spherical and unstalked.

The paired ovaries lie ventrally in the usual position just behind the brain. Parovaries are usually present. The oviducts unite above the atrium to form a common oviduct which receives the shell glands for its entire length, and which opens into the roof of the male atrium anteriorly to the bursal duct. In mature specimens the vitellaria are extensive. The bursa copulatrix is saclike and the bursal duct curves over the copulatory apparatus, widening as it does so, to open into the atrium above the gonopore (Fig. 7). 
Fig. 6 Phagocata velata. Drawing of a living animal from Erbsville, Waterloo County, Ontario.


Fig. 7 Phagocata velata. Sagittal section, viewed from the left side, through the copulatory apparatus of a specimen from Laurel Creek, Waterloo County, Ontario (ROM C272A). 
The follicular testes are predominantly dorsal and extend throughout the body length. Some fusion between adjacent follicles may occur. In mature specimens the vasa deferentia become greatly enlarged and convoluted in the pharyngeal region and thus form false seminal vesicles. They often show recurvature on entering the penis bulb.

The penis consists of a hemispherical muscular bulb and a broadly conical papilla, which fills the male atrium. The intrabulbar seminal vesicle is usually very small and the ejaculatory duct, which opens at the tip of the papilla, has a ventral diverticulum that is characteristic of the species (Fig. 7:di).

\section{Remarks}

This brief description is given so as to facilitate contrast and comparison with that of Hymanella retenuova. In all essential respects our material conforms with the more detailed descriptions of the species provided by Castle and Hyman (1934) and Kenk (1944, 1972).

The declaration that the Phagocata gracilis monopharyngea of Hyman is identical with $P$. velata requires justification here. In February 1971 Dr. Jerry H. Carpenter collected several immature planarians from the type locality of Hyman's species in Washington County, Iowa. These planarians were cultured in Washington, D.C., and a few sexual specimens were obtained, some after being fed on crushed sexual specimens of Dugesia dorotocephala, a method introduced by Grasso (1974). The planarian proved to be Phagocata velata, showing the characteristic diverticulum of the ejaculatory duct and predominantly dorsal testes. Hyman's cotype slides (AMNH 326-327) of $P$. gracilis monopharyngea also show the ejaculatory duct as irregularly convoluted, rather than smooth, as it was drawn in her fig. 1, which may indicate the presence of a diverticulum. Her specimen apparently either was not fully mature or was past the maturity stage, but there can be little doubt that she was dealing with $P$. velata.

\section{Distribution and Biology}

Kenk (1972) records $P$. velata as occurring in springs, streams, and spring-fed ponds, apparently all across the continent, but the study of sexual material has occurred only in eastern North America. The recognition that $P$. vernalis is not a valid species means that Kenk's (1972) distributional data referring to temporary ponds can also be applied to $P$. velata. The exact range of $P$. velata is not known, and in western North America there are superficially very similar species, which show fragmentation, and which nevertheless are morphologically and karyologically distinct (Ball and Gourbault, 1975).

The occurrence of a single species in such diverse localities as vernal ponds and spring-fed streams is an unusual phenomenon. Established records report it from springs, streams, and vernal ponds in Ontario (Kenk, 1943; Ball and Fernando, 1968; Williams, 1976); Quebec (Ball and Fernando, 1970); a temporary pool in Minnesota (Higley, 1918); springs, streams, and vernal pools in Michigan (Kenk, 1944, 1949; Smrchek, 1972); streams in New York (Hyman, 1955; Whitehead, 1965); a vernal pool in Massachusetts (Castle, 1941); springs and ponds in Nebraska (Stringer, 1909); a spring in Iowa (Tilly, 1968); from Wisconsin (Castle and Hyman, 1934); 
temporary pools and ditches in Illinois (Child, 1913, 1914; Higley, 1918); springs and temporary pools in Indiana (Castle, 1927; Castle and Hyman, 1934); Colorado (Hyman, 1931; Ward, 1964); spring-fed brooks and a cave in Missouri (Alexander and Price in Castle, 1928; Lewis, 1974); a stream in Kentucky (Minckley, 1963); springs, streams, and vernal ponds in Tennessee (Givens, 1953; Darlington and Chandler, 1970, 1972; Chandler, 1972; Phillips et al., 1974); and in the Savannah River, South Carolina, and Georgia (Wurtz, 1953).

The following unpublished records, verified by the study of sexual specimens, may be added to these habitats. Wisconsin: Nevin Fish Hatchery, Dane County, collected by R. Kenk, 23 August 1967. Missouri: spring at Festus, Jefferson County, collected by R. Kenk, 4 October 1967. Illinois: intermittent stream at Vienna, Johnson County, collected by Jerry Lewis, 2 March 1974, matured in culture.

The seeming absence, or rarity, of the species from the states of the eastern seaboard, and also from the Canadian maritime provinces, is particularly noteworthy.

The species is not frequently found in the sexual state, which, if it occurs, is usually in the cold season. Asexual reproduction is by multiple fragmentation and encystment. Fragmentation is usually preceded by a partial loss of pigment and often fission planes can be discerned (Fig. 8). Each fragment becomes encased in mucus, which hardens, and in this state endures the dry period of vernal habitats (Castle, 1927, 1928). However, the belief that in the two types of habitat, vernal ponds and spring-fed streams, the life cycle is entirely different (Castle and Hyman, 1934) is erroneous, for in late autumn and winter it is possible to find sexual specimens in the


Fig. 8 Phagocata velata. Fragmentation and encystment in specimens from Erbsville, Ontario. 
vernal pond at Crieff, Ontario. In summer, however, the same population shows the fragmentation phenomenon as the pool dries up. This is perfectly consistent with the viewpoint of Castle and Hyman (1934) that falling temperature favours sexual, and rising temperature asexual, reproduction. It is not clear why they believed sexual reproduction did not occur in vernal ponds in winter.

In Ontario, at least, $P$. velata usually carries the epifaunal ciliate Urceolaria mitra (Ball and Fernando, 1968), and frequently specimens heavily infested with sporozoan cysts are found.

\section{Karyology (Fig. 9)}

Five populations of $P$. velata were investigated karyologically. The Ontario specimens came from a spring-fed stream near Erin, and from vernal ponds at Crieff and Erbsville, both near Waterloo, the latter pond being the one that also harbours $H$. retenuova. From Michigan we obtained specimens from the Ponds 1 and 2 in which it was formerly believed $P$. vernalis occurred (Kenk, 1944, 1949).

Most of the specimens were immature and gametogenesis was impossible to study. In those few specimens that were sexual only the first stages of spermatogenesis and oogenesis were observed. Thus, as with Hymanella, our data are derived from analyses of the chromosome sets in regenerative blastema cells. Some slight differences were found according to the populations studied.

In all the somatic metaphase plates of the population from Crieff the chromosome set was equal to 96 . In the population from Erbsville, the cohabitants of $H$. retenuova, most of the metaphase plates observed possessed 96 chromosomes (Fig. 9), but two plates with 72 chromosomes and one with 84 chromosomes were present. In the population from Erin the mosaic is more evident for although most metaphase plates possessed 96 elements it was possible to find, in the same specimen, some plates with 84, 72 (Fig. 9), and even 60 chromosomes. In the populations from Michigan lower values were frequent; 60 was then the common number, though plates with 72 and 84 chromosomes were also found. The size of the elements varies from 1.5 to $4.5 \mu \mathrm{m}$.

All these high numbers may be referred to a polyploid condition with 12 as an obvious basic number. This viewpoint is clearly supported by the karyograms because in camera lucida drawings of about 50 metaphase plates it was always possible to discern some especially large chromosomes, the number of the latter corresponding exactly to the different levels of polyploidy, assuming a basic number of 12. Thus there were eight for a complement of 96 , seven for 84 , six for 72 and five for 60 .

Because of the high degree of polyploidy in this species a detailed karyometric study could not be carried out. Only the largest elements have been measured and always they are at least twice the length of the second chromosomes. Hymanella and other Phagocata species also have one pair of comparatively large chromosomes.

\section{RECOGNITION OF THE SPECIES}

Once living specimens of both the above species have been seen side by side, it is easy to distinguish between them accurately by eye.

Of the two, Hymanella retenuova is somewhat lighter and more transparent in colour, generally flatter in the dorsoventral plane, and broader in proportion to its 
A
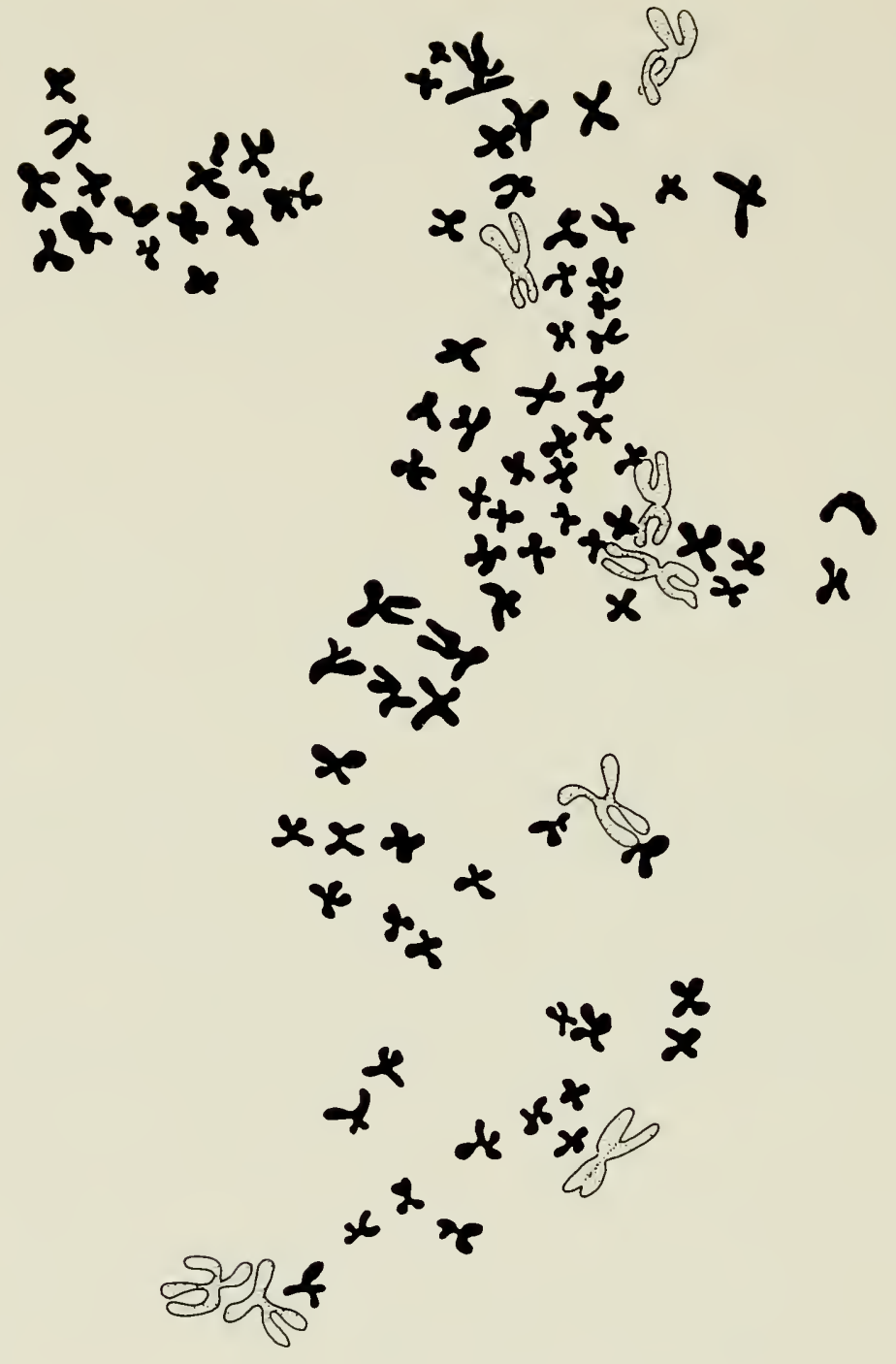

B

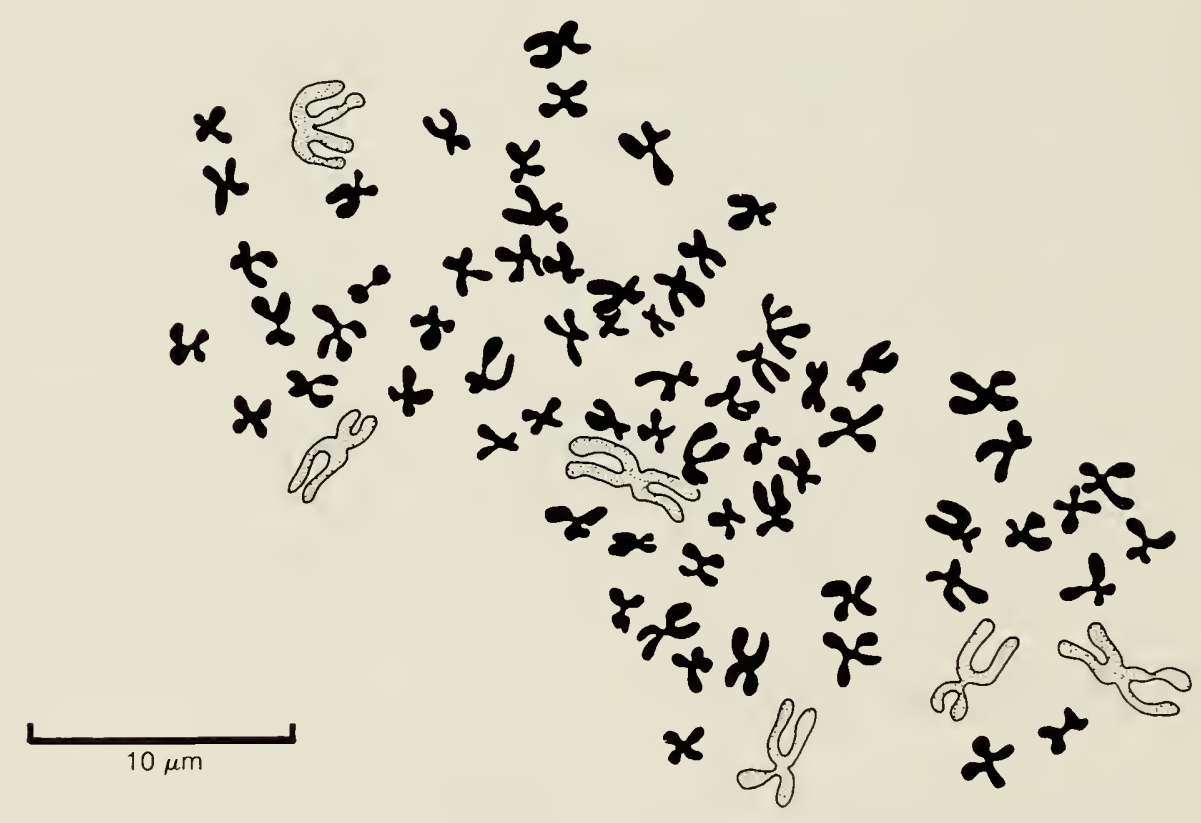

Fig. 9 Phagocata velata. Diagrams of metaphase plates showing (a) 96 chromosomes in a specimen from Erbsville, Waterloo County, Ontario and (b) 72 chromosomes in a specimen from Erin, Wellington County, Ontario. The large "'marker" chromosomes are lightly shaded. 
length. It is by examination of the head, however, that recognition is most easily achieved. The head of $H$. retenuova is broader and rounder, whereas the head of $P$. velata often is spatulate or slightly trilobed. Furthermore, the eyes of $P$. velata are clearly more anterior in position than those of $H$. retenuova. Finally, the anterior ramus of the intestine rarely extends beyond the eyes in $H$. retenuova and frequently does so in $F$. velata. These characteristics are illustrated in Figs. 1 and 6.

Anatomically $H$. retenuova is characterized in the male phase principally by the ventral, prepharyngeal, fused testes, and in the female phase by the large atrium lined by a papillose epithelium. $P$. velata is characterized by its dorsal, follicular testes distributed throughout the body length, and, more importantly, by the presence of a distinct ventral diverticulum of the ejaculatory duct.

Karyologically, the high degree of polyploidy of $P$. velata, with a basic chromosome number of 12 , contrasts with the diploid condition of $2 \mathrm{n}=38$ found in $H$. retenuova.

Biologically, $H$. retenuova, markedly protandrous, reproduces only sexually and produces a distinctive oval and thick-shelled cocoon that is retained in the body for many days. $P$. velata reproduces either sexually or asexually. In laboratory conditions this species usually shows loss of pigment, fragmentation, and encystment, within several days (Fig. 8).

\section{The Status of Phagocata vernalis and its Relationship to Hymanella retenuova}

Phagocata vernalis was originally described from one sexual specimen and one overmature animal collected in 1941 from a vernal pond in Michigan (Kenk, 1944). The most characteristic feature of the new species was its possession of fused testes, a very rare feature in aquatic planarians. Partially fused testes have been described in some European triclads such as Crenobia alpina (Chichkoff, 1892) and Phagocata opisthogona (Kenk, 1936), and may also occur in Phagocata velata. But complete fusion hitherto has been known only in Phagocata vernalis and Rhodax evelinae from Brasil (Marcus, 1946). The latter is an aberrant form in many respects and there can be little doubt that it forms an evolutionary line quite distinct from Phagocata (Ball, 1974, 1977b).

During a survey of the freshwater planarians of eastern North America from 1968 to 1971 , Ball made many attempts to recover $P$. vernalis from the type locality. Numerous specimens of Phagocata were obtained, but none were mature and so specific identification was impossible (as noted by Kenk [1944], $P$. vernalis and $P$. velata can be distinguished only by features of their copulatory apparatus).

Concurrently with these attempts, several similar localities in southern Ontario were also sampled with the result that all pigmented species of Phagocata that were found in a mature state proved to be Phagocata velata. However, early in 1968 a few specimens of Hymanella retenuova, identified from their unusual cocoons, were discovered in a vernal pond that also harboured a large population of what appeared to be asexual Phagocata velata. Sections of the former specimens revealed that they possessed fused testes just as described for $P$. vernalis and contrary to the original 
description of $H$. retenuova by Castle (1941). Subsequent to Castle's description neither Hyman (1955) nor Longest (1966) made any reference in their descriptions to the testes of the species.

For the next two years attempts to recover Hymanella from the same pond so as to confirm the morphological findings were unsuccessful. Then in 1971 it was noted that in a sample of supposed Phagocata velata collected at the same site individuals were either heavily epifaunated with Urceolaria mitra or were entirely free of them. Sections revealed that those specimens free of the epifaunal ciliates were Hymanella retenuova, whereas the others presumably were Phagocata velata, which is otherwise known to harbour the peritrichs (Ball and Fernando, 1968). This then gave a means of separating the two species from this site without recourse to sectioning, and subtle, but reliable, differences in external appearance between them were discovered. Analysis of sections of the newly discovered Hymanella confirmed the earlier morphological findings, notwithstanding Castle's (1941) description, as presented in the species description above.

In describing Phagocata vernalis Kenk (1944) listed four characters in which it differed from $P$. velata:

i) Testes few, prepharyngeal, fused to form a compound testis on the medial side of each ventral nerve cord.

ii) Ejaculatory duct a narrow tube, without diverticulum.

iii) Common oviduct short, only its upper half with shell glands.

iv) Bursa with two anteroventral horns.

These are all features that apply also to Hymanella retenuova when the description of that species is revised to accommodate data from the new specimens. Moreover, a comparison of the holotype of $P$. vernalis (USNM 43108) with the Ontario material of Hymanella, mostly female-mature, revealed that the anatomy and histology of the two species is very similar in a number of other respects. In both, the atrial epithelium consists of unusually high cells, and both species possess a reduced penis bulb and lack a seminal vesicle. Furthermore, in neither species do the vasa deferentia form expanded seminal vesicles, instead these enter the penis bulb, without prior convolutions, directly from the ventroanterior aspect. In Phagocata velata there are greatly expanded and highly convoluted false seminal vesicles in mature specimens, and these enter the penis bulb anterolaterally. Histologically, the penes of $H$. retenuova and $P$. vernalis are also very similar, and in this female phase the terminal part of the papilla lacks a distinct muscle coat, in contrast to $P$. velata.

Thus, in many important respects $P$. vernalis is closer to $H$. retenuova than it is to $P$. velata. The major difference between the two species lies in the size of the penis papilla (cf. Kenk, 1944: fig. 3; and Fig. 2 of this paper), that of $P$. vernalis being much the larger.

In the original description of $H$. retenuova, Castle (1941) drew attention to the fact that the penis was degenerate and lacked a bulb; the papilla was described as not exceeding $60 \mu \mathrm{m}$ in length. Later Hyman (1955) redescribed the species from Delaware and North Carolina and agreed with Castle that the penis lacked a normal bulb, but her figures show the papilla to be somewhat larger than indicated by Castle. In the first Ontario specimens a more muscular penis bulb clearly is present, and the papilla is relatively large, being up to $180 \mu \mathrm{m}$ (Fig. 2). It seems likely that both 
Castle and Hyman have examined only specimens in which the male reproductive system is undergoing atrophy and that the differences are related to the life cycle of the species.

Castle (1941) suggested that Hymanella retenuova was markedly protandrous. His conclusion was based on his erroneous interpretation of the testes. Nonetheless he is right. The penis papilla of $H$. retenuova as described by Castle and Hyman could hardly function as an intromittent organ in view of its minute size compared with the volume of the male atrium. On the other hand, the male atrium of $P$. vernalis is structurally very similar to that of $H$. retenuova, and yet the penis papilla completely fills it, forming a perfectly functional intromittent organ.

It is clear, then, that Phagocata vernalis represents male mature Hymanella retenuova, i.e., specimens of the latter at the early stages of development of the copulatory organs, which regress after copulation has taken place. It is noteworthy that the sole fully mature specimen of $P$. vernalis was collected in January, from under ice, much earlier than any of the hitherto studied specimens of $H$. retenuova. In Kenk's specimen the fused testes are at an early stage of spermatogenesis and contain mostly spermatocytes and primary spermatids, whereas in the Ontario specimens mature sperm were present. The only other sexual specimen of $P$. vernalis collected by Kenk was taken in April 1941 and was overmature; certainly its condition (Fig. 10 ) is consistent with its being $H$. retenuova (Fig. 2).

As a final check, in 1974 Ball and Gourbault jointly reinvestigated the ponds originally studied by Kenk $(1944,1949)$. Hymanella retenuova could now be recognized by eye, and specimens were found in both ponds. Interestingly enough they occurred only in dug-out samples of debris returned to the laboratory and allowed to stand overnight. On-site collecting by examining leaves and debris yielded only specimens of Phagocata. This suggests that there may be a spatial separation of the species, perhaps related to food preferences, within the ponds. Living specimens



Fig. 10 "Phagocata vernalis". Sagittal section, viewed from the left side, through the copulatory apparatus of the paratype (USNM 43109). Compare with Fig. 2 of Hymanella retenuovi. 
of the Phagocata species were given to Kenk in Washington who cultured them. A few developed traces of reproductive organs the morphology of which was perfectly consistent with their being identified as Phagocata velata. Furthermore, our karyological data revealed that whereas $H$. retenuova had a diploid complement of 38, the Phagocata species from the Michigan ponds showed a high degree of polyploidy and a chromosome morphology similar to that of Phagocata velata from various localities in Ontario. The conclusion that Phagocata vernalis represents a mixed description of Phagocata velata and male-mature Hymanella retenuova thus seemed inescapable, the more so when it is realized that in all vernal ponds from which there are published records of $H$. retenuova, $P$. velata also occurs.

Apart from the type locality in Michigan, Phagocata vernalis has been recorded at only one other site. Darlington and Chandler (1972) collected the species in a vernal pond near Memphis, Tennessee. Darlington (1974, in litt.) mentioned that in a laboratory culture, specimens produced cocoons that were retained for many days in the body, just as described for $H$. retenuova. Other specimens were observed to encyst, just as in $P$. velata. Furthermore, Darlington noted some minor differences between his specimens and that described by Kenk (1944). In particular he found the shell glands to be very extensive and the atrium to be elongate and lined with a tall papillose epithelium, these both being features of the known specimens of $H$. retenuova. On the other hand the penis papilla is large, yet in one case only half fills the male atrium, but its histological structure is more similar to that of $H$. retenuova than to that of $P$. velata. There seems little doubt that Darlington, too, was dealing with a mixed population of $H$. retenuova and $P$. velata.

\section{Planarians in Temporary Waters}

Although temporary waters have been studied the world over (e.g., Rzoská, 1961) it is only within the Northern Hemisphere that freshwater planarians specifically adapted to these habitats are well known, in particular members of the genus Phagocata, and its close relative Hymanella. The North American species Hymanella retenuova has a modified sexual reproductive cycle in which a resistant cocoon is produced. In the species of Phagocata there is a modification of the asexual cycle. It has long been known that the widespread European species $P$. vitta can encyst under unfavourable conditions (Stankovic and Komárek, 1927), but there is no prior fragmentation even though the species reproduces predominantly by fission. In the North American species $P$. fawcetti and $P$. velata there is multiple fragmentation prior to encystment, and whereas sexual reproduction also occurs in both species asexuality is more usual.

Apart from these Planariidae we know only of certain members of the Dugesiidae that have been found in intermittent streams. Some species of the endemic Notogaean genus Spathula are known from streams that dry up in the summer (Ball, 1977a; Hay and Ball, 1979). Nothing is known of their mechanism for surviving the dry periods but it is noteworthy that in Australia the species of this genus occupy the kinds of habitats that in the Northern Hemisphere are typically inhabited by planariid species of the genera Phagocata, Crenobia, and Polycelis. The Planariidae are absent from 
the Southern Hemisphere and it is also worth noting that in the Serra do Cipo of southern Brazil no planarians were found in the rich temporary pools there, although species of Dugesia were common in neighbouring streams (Ball, unpublished data). It seems that here is a vacant niche.

Phagocata vitta is commonly found in wells and in ground water that may appear on the surface for a few months of the year; its ecology has been discussed in detail most recently by Dahm $(1949,1958)$. Since most, if not all, freshwater planarians are capable of secreting a protective mucous coat under adverse conditions they are to some extent preadapted for intermittent waters. Certainly there would be strong selection pressure favouring a secretion resistant to desiccation and its origin and development is easily understood for species that are well able to live sexually or asexually in surface waters that may be permanent though subject to irregular partial drying, as is the case for the three species of Phagocata.

The situation for Hymanella retenuova is entirely different. This species obligatorily reproduces sexually and does not occur in permanent water-bodies. Thus the adaptation to life in temporary waters must involve the reproductive cycle and without a resistant egg capsule the species could not invade temporary pools, for it could not survive the dry periods.

There is a second feature that sets $H$. retenuova apart from all other freshwater planarians, its marked protandry. Most aquatic planarians are simultaneous hermaphrodites and self-fertilization is an exception rather than the rule (Gourbault and Benazzi, 1975). In fact morphological adaptations that prevent selfing have been demonstrated in a number of freshwater planarians (Ullyott and Beauchamp, 1931). Analogous adaptations are known from a wide group of organisms (Ghiselin, 1974). However, the potential deleterious effects of selfing can be avoided by the development of sequential hermaphroditism, either as protogyny or protandry. This phenomenon also would reduce the probability of inbreeding among siblings (Ghiselin, 1969). Assuming similar growth and maturation rates, a not unreasonable assumption in the case of Hymanella retenuova with its very rapid life cycle in a rich environment, then the members of a given brood would not be able to cross with one another, but only with those members of an earlier hatching brood in the case of protandrous populations. The restriction of inbreeding among siblings may well be an important factor in a dense and well circumscribed population where possibilities for dispersal away from the parental zone are so limited. 


\section{Acknowledgements}

This project was begun by I. R. Ball in 1968 at the University of Waterloo as a morphological and biological study of the populations from Michigan and Ontario. It was continued at the Royal Ontario Museum and the Zoological Museum, Amsterdam. The karyological work was principally the responsibility of $\mathrm{N}$. Gourbault, and was begun at the Royal Ontario Museum and completed in Paris. Study of the Maryland material and the culturing of specimens from Michigan and Maryland so as to obtain all phases of the life cycle were carried out by R. Kenk at the Smithsonian Institution in Washington. The final paper was written jointly and authorship is alphabetical.

To the officers of the institutions mentioned above we are grateful for the facilities that were made available. We express our thanks also to Dr. W. P. Kovalak, now of Allegheny College, Meadville, Pa., for his help on fieldwork in Michigan, and to Mr. Arnold Norden (Towson, Md.) who kindly permitted us to publish his collection data on Hymanella. To Prof. J. T. Darlington and Prof. C. M. Chandler we are grateful for the loan of material from Tennessee and for the facilities made available for our work there. Figs. 2, 3, 7, 8, and 10 are the work of Ms. Maria Tran Thi Vinh-Hao; Mr. Julian Mulock drew Figs. 1 and 6. We are indebted to them both.

Dr. Gourbault's visit to the Royal Ontario Museum was made possible by an award from the National Research Council of Canada under its Canada-France Cultural Exchange Programme. Completion of this project was made possible by NRCC Operating Grant A0016 awarded to I. R. Ball. We acknowledge with gratitude this support. 


\section{Summary}

In eastern North America two species of freshwater planarians, Phagocata velata and Hymanella retenuova, have successfully adapted themselves to living in temporary pools. The typical vernal pool form, $P$. vernalis, can be shown to be conspecific with the latter species on morphological, karyological, and biological grounds.

Hymanella reproduces only sexually; it is markedly protandrous and produces a thick-shelled cocoon which is retained for several days in the body, and which survives the dry periods of the habitat. Phagocata velata reproduces both sexually and asexually, sometimes in the same habitat. The cocoons of this species are produced in the cold season and presumably they are not resistant to desiccation. $P$. velata survives the dry period by modification of the asexual cycle; at the onset of adverse conditions multiple fragmentation or fission occurs and the pieces secrete a coat of mucus around themselves. This hardens and enables the fragments to survive the dry season. With the reappearance of water in the habitat these fragments hatch from the cysts as small but completely formed worms.

The karyotype of Hymanella retenuova consists of 38 elements and is very similar to that of Phagocata gracilis and $P$. fawcetti. In contrast $P$. velata shows a high degree of polyploidy with numbers up to 96 ; the basic set seems to be 12 .

Whereas it is only known that species of Hymanella and Phagocata possess special adaptations for survival in temporary waters, recent work is indicating that in Australia species of the genus Spathula (Dugesiidae) are not uncommon in intermittent streams. The mechanisms of recolonization after the drought period have not been investigated. 


\section{Sommaire}

Deux espèces de Triclades paludicoles, Phagocata velata et Hymanella retenuova, sont parfaitement adaptées aux conditions précaires d'existence dans les mares temporaires de l'est de l'Amérique du Nord. $P$. vernalis, forme typique des mares de printemps, correspond à la dernière espèce, comme le fait apparaître une étude basée sur leur morphologie, leur caryologie et leur biologie.

Hymanella a un mode de reproduction sexuée; elle est nettement protandre et produit un cocon à enveloppe épaisse, conservé plusieurs jours dans l'atrium et capable de survivre lors de l'assèchement du biotope. Cette protandrie, toute particulière, pourrait être considérée comme responsable de la formation d'un cocon préadaptant $H$. retenuova à la vie en mare temporaire, où elle peut exploiter une niche écologique disponible et riche.

$P$. velata présente les deux modes de reproduction, sexué et asexué, quelquefois dans le même habitat. Ses cocons sont produits en saison froide et ils ne peuvent résister à la dessiccation.

$P$. velata survit à la sécheresse en modifiant son cycle asexué; dès l'apparition de mauvaises conditions, l'animal se scinde et les divers fragments secrètent une enveloppe de mucus qui durcit et leur permet de subsister. Avec le retour de l'eau dans le biotope chaque fragment ayant régénéré, des planaires complètes bien que très petites, s'echappent sortent de ces kystes.

Le caryotype d' $H$. retenuova comprent 38 éléments (comme celui de $P$. fawcetti). Au contraire, $P$. velata possède généralement un haut degré de polyploïdie, atteignant jusqu'à 96 chromosomes. (Le nombre de base pourrait être 12.)

Parallelement, de récents travaux concernant des espèces australiennes du genre Spathula indiquent que ses formes ne sont pas rares dans les cours d'eau intermittants.

Et si l'adaptation de certaines espèces des seuls genres Phagocata et Hymanella à la vie en mares temporaires a pu être mise en evidence, en revanche l'étude des méchanismes de recolonisation après la période de sécheresse n'a pas été abordée. 


\section{Zusammenfassung}

Zwei Arten von Süsswasserplanarien im östlichen Nordamerika, Phagocata velata und Hymanella retenuova, haben sich erfolgreich an das Leben in vorübergehenden Tümpeln angepasst. Die typische Frühjahrstümpelform $P$. vernalis erweist sich auf morphologischer, karyologischer und ökologischer Grundlage als konspezifisch mit Hymanella.

Hymanella hat nur geschlechtliche Fortpflanzung. Die Art ist ausgesprochen protandrisch und bildet eine dickschalige Eikapsel, die mehrere Tage im Leibe bleibt and die den Trockenperioden der Tümpel widersteht. $P$. velata pflanzt sich geschlechtlich und ungeschlechtlich fort, manchmal im selben Tümpel. Die Eikapseln dieser Art werden während der kalten Jahreszeit abgelegt, aber sie widerstehen dem Austrocknen wahrscheinlich nicht. $P$. velata überlebt die Trockenperiode durch eine Modifizierung des ungeschechtlichen Cyclus; wenn die Lebensbedingungen sich verschlechtern, Fragmentierung oder multiple Fission treten ein und die Stückchen umgeben sich mit einer Schleimhülle, die erhärtet und das Überleben der Fragmente ermöglicht. Wenn die Tümpel sich wieder füllen, schlüpfen die Stückchen aus den Zysten als kleine, aber vollständig ausgebildete Würmer.

Der Karyotypus von Hymanella retenuova besteht aus 38 Elementen und ist dem von Phagocata gracilis und $P$. fawcetti sehr ännlich. $P$. velata hingegen zeigt eine hochgradige Polyploidie mit Zahlen die 96 erreichen. Die Grundgarnitur scheint 12 zu sein.

Während wir wissen, dass Hymanella- und Phagocata-Arten an das Leben in vorübergehenden Gewässern angepasst sind, deuten neuere Untersuchungen an, dass in Australien Arten der Gattung Spathula (Dugesiidae) häufig in vorübergehenden Bächen leben. Die Mechanismen ihres Wiederauftretens nach trockenen Perioden sind noch nicht untersucht. 


\section{Literature Cited}

BALL, I. R.

1969 An annotated checklist of the freshwater Tricladida of the Nearctic and Neotropical regions. Canadian Journal of Zoology 47:59-64.

1974 A contribution to the phylogeny and biogeography of the freshwater triclads (Platyhelminthes, Turbellaria). In Riser, N. W. and M. P. Morse, eds., Biology of the Turbellaria. New York, McGraw-Hill, pp. 339-401.

1975 Contributions to a revision of the marine triclads of North America: the monotypic genera Nexilis, Nesion and Foviella (Turbellaria, Tricladida). Canadian Journal of Zoology $53: 395-407$.

1977a A monograph of the genus Spathula (Platyhelminthes, Turbellaria, Tricladida). Australian Journal of Zoology, Supplementary Series 47:1-43.

$1977 \mathrm{~b}$ On the phylogenetic classification of aquatic planarians. In Karling, T. G. and M. Meinander, eds., The Alex. Luther Centennial Symposium on Turbellaria. Acta Zoologica Fennica $154: 21-35$.

BALL, I. R. and C. H. FERNANDO

1968 On Urceolaria mitra (Protozoa, Peritricha), epizoic on North American flatworms. Canadian Journal of Zoology 46:981-985.

1970 Freshwater triclads (Platyhelminthes, Turbellaria) from Anticosti Island. Naturaliste canadien $97: 331-336$

BALL, I.R. and N. GOURBAULT

1975 The morphology, karyology and taxonomy of a new freshwater planarian of the genus Phagocata from California (Platyhelminthes, Turbellaria). Royal Ontario Museum, Life Sciences Contributions 105:1-19.

BENAZZI, M. and N. GOURBAULT

1974 Étude caryologique de quelques populations hypogées de la planaire Phagocata (Fonticola) vitta (Dugès, 1830). Caryologia 27:467-484.

CASTLE, W. E.

1927 The life history of Planaria velata. Biological Bulletin 53:139-145.

1928 An experimental and histological study of the life-cycle of Planaria velata. Journal of Experimental Zoology $51: 417-483$.

1941 The morphology and life-history of Hymanella retenuova, a new species of triclad from New England. American Midland Naturalist 26:85-97.

CASTLE. W. E. and L. H. HYMAN

1934 Observations on Fonticola velata (Stringer), including a description of the anatomy of the reproductive system. Transactions of the American Microscopical Society 53:154-171.

CHANDLER, C. M.

1972 Planarians of Tennessee. Journal of the Tennessee Academy of Science 47:62.

CHICHKOFF, G.

1892 Recherches sur les Dendrocoeles d'eau douce (Triclades). Archives de Biologie 12:435-568.

CHIDESTER, F. E

1908 Extrusion of the winter egg capsule in Planaria simplississima. Biological Bulletin $15: 226-228$.

CHILD, C. M.

1913 The asexual cycle of Planaria velata in relation to senescence and rejuvenation. Biological Bulletin 25:181-203.

1914 Asexual breeding and prevention of senescence in Planaria velata. Biological Bulletin 26:286-293. 
DAHM, A. G.

1949 Phagocata ( = Fonticola) from South Sweden (Turbellaria, Tricladida, Paludicola); taxonomical, ecological, and chorological studies. Lunds Universitets Årsskrift, n.s. $45(7): 1-32$.

1958 Taxonomy and ecology of five species groups in the family Planariidae (Turbellaria, Tricladida, Paludicola). Malmö, Nya litografen. 241 pp.

1964 The taxonomic relationships of the European species of Phagocata $(?=$ Fonticola) based on karyological evidence (Turbellaria, Tricladida, Paludicola). Arkiv för Zoologi, Ser. 2, $16: 481-509$.

DARLINGTON, J. T. and C. M. CHANDLER

1970 A survey of the epigean triclad turbellarians of Tennessee. American Zoologist 10:547-548. [Abstract]

1972 A survey of the epigean triclad turbellarians of Tennessee. American Midland Naturalist $88: 158-166$

GHISELIN, M. T

1969 The triumph of the Darwinian method. Berkeley, University of California Press. 287 pp.

1974 The economy of nature and the evolution of sex. Berkeley, University of California Press. 346 pp.

GIVENS, J. R.

1953 The triclad Turbellaria of the Nashville area, with supplementary records from the highlands, North Carolina region. M.S. Thesis, Vanderbilt University. 44 pp.

GOURBAULT, N. and M. BENAZZI

1975 Karyological data on some species of the genus Cura (Tricladida, Paludicola). Canadian Journal of Genetics and Cytology 17:345-354.

GRASSO, M

1974 Some aspects of sexuality and agamy in planarians. Bolletino di Zoologia 41:379-394.

HALDEMAN, S. S

1840 Supplement to number one of "A monograph of the Limniades or freshwater univalve shells of North America." Philadelphia, n.p. 3 pp.

HAY, D. A. and I. R. BALL

1979 Contributions to the biology of freshwater planarians (Turbellaria) from the Victorian Alps, Australia. Hydrobiologia 62:137-164.

HIGLEY, R.

1918 Morphology and biology of some Turbellaria from the Mississippi Basin. Illinois Biological Monographs 4:197-288.

HYMAN, L. H.

1931 Studies on the morphology, taxonomy, and distribution of North American triclad Turbellaria, IV: recent European revisions of the triclads, and their application to the American forms, with a key to the latter and new notes on distribution. Transactions of the American Microscopical Society $50: 316-335$.

1937 Studies on the morphology, taxonomy, and distribution of North American triclad Turbellaria, VII: the two species confused under the name Phagocata gracilis, the validity of the generic name Phagocata Leidy, 1847, and its priority over Fonticola Komárek, 1926. Transactions of the American Microscopical Society 56:298-310.

1945 North American triclad Turbellaria, XI: new, chiefly cavernicolous, planarians. American Midland Naturalist 34:475-484.

1955 Descriptions and records of fresh-water Turbellaria from the United States. American Museum Novitates 1714:1-36. 
1930 Beiträge zum System der Probursalier (Tricladida Paludicola). Zoologischer Anzeiger $89: 289-302$.

1936 Eine neue Höhlentriklade, Fonticola opisthogona n. sp. Zoologischer Anzeiger 113:305311.

1943 Notes on the planarian fauna of Canada. Canadian Field-Naturalist 57:5-6.

1944 The fresh-water triclads of Michigan. Miscellaneous Publications of the Museum of Zoology, University of Michigan 60:1-44.

1949 The animal life of temporary and permanent ponds in southern Michigan. Miscellaneous Publications of the Museum of Zoology, University of Michigan 71:1-66.

1970 Freshwater triclads (Turbellaria) of North America, II: new or little known species of Phagocata. Proceedings of the Biological Society of Washington 83:13-34.

1972 Freshwater planarians (Turbellaria) of North America. Biota of Freshwater Ecosystems, Identification Manual no. 1. Washington, D.C., U.S. Environmental Protection Agency. 81 pp.

1974 Index of the genera and species of the freshwater triclads (Turbellaria) of the world. Smithsonian Contributions to Zoology 183:1-90.

LEIDY, J.

1847 Description and anatomy of a new and curious sub-genus of Planaria. Proceedings of the Academy of Natural Sciences of Philadelphia 3:248-251.

LEVAN, A., K. FREDGA, and A. A. SANDBERG

1964 Nomenclature for centromeric position on chromosomes. Hereditas 52:201-220.

LEWIS, $\mathbf{J}$

1974 The invertebrate fauna of Mystery Cave, Perry County, Missouri. Missouri Speleology 14(4): 1-19.

LONGEST, W. D.

1966 The freshwater Tricladida of the Florida Parishes of Louisiana. Ph.D. Thesis, Louisiana State University. $95 \mathrm{pp}$.

MARCUS, E.

1946 Sôbre Turbellaria brasileiros. Universidade de Saô Paulo, Boletim de Faculdade de Filosofia Ciências e Letras, Zoologia 11:5-253.

MINCKLEY, W. L.

1963 The ecology of a spring stream, Doe Run, Meade County, Kentucky. Wildlife Monographs $11: 1-124$.

PHILLIPS, J., M. WELLS, and C. M. CHANDLER

1974 Metabolism of DDT by the freshwater planarian, Phagocata velata. Bulletin of Environmental Contamination and Toxicology 12:355-358.

RZOSKA, J

1961 Observations on tropical rainpools and general remarks on temporary waters. Hydrobiologia $17: 265-286$.

SMRCHEK, J. C.

1972 Extension of range of the triclad turbellarian Phagocata gracilis (Haldeman). Transactions of the American Microscopical Society $91: 596-599$.

STANKOVIC, S. and J. KOMÁREK

1927 Die Süsswasser-Tricladen des Westbalkans und die zoogeographischen Problem dieser Gegend. Zoologische Jahrbücher, Abteilung für Systematik, Ökologie und Geographie der Tieren $53: 591-674$. 
STRINGER, C. E.

1909 Notes on Nebraska Turbellaria with descriptions of two new species. Zoologischer Anzeiger $34: 257-262$.

TILLY, L. J.

1968 The structure and dynamics of Cone Spring. Ecological Monographs 38:169-197.

ULLYOTT, P. and R. S. A. BEAUCHAMP

1931 Mechanisms for the prevention of self-fertilization in some species of fresh-water triclads. Quarterly Journal of Microscopical Science, n.s. 74:477-489.

WARD, J. D. Q.

1964 Triclad Turbellaria in a Colorado altitudinal transect. M. A. Thesis, University of Colorado. $28 \mathrm{pp}$.

WHITEHEAD, M.

1965 The triclads of Cattaraugus County, New York. Ph.D. Thesis, Saint Bonaventure University. 128 pp.

WILLIAMS, W. D.

1976 Aquatic invertebrates inhabiting agricultural tile systems in southern Ontario. Canadian Field-Naturalist 90:193-195.

WURTZ, C. B.

1953 The invertebrate fauna. In Savannah River Biological Survey, South Carolina and Georgia, June 1951-May 1952. Final report for E.I. du Pont de Nemours and Co., Savannah River plant. Philadelphia, Academy of Natural Sciences of Philadelphia, pp. 64-87, 241-252. 


. 
ISBN 0-88854-274-7 ISSN 0384-8159 